Article

\title{
Dietary Fructose Enhances the Ability of Low Concentrations of Angiotensin II to Stimulate Proximal Tubule $\mathrm{Na}^{+}$Reabsorption
}

\author{
Agustin Gonzalez-Vicente ${ }^{1,2, *}$, Pablo D. Cabral ${ }^{1,3,4}$, Nancy J. Hong ${ }^{1}$, Jessica Asirwatham ${ }^{1}$, \\ Nianxin Yang ${ }^{1}$, Jessica M. Berthiaume ${ }^{1}$, Fernando P. Dominici ${ }^{2,5}$ and Jeffrey L. Garvin ${ }^{1}$ \\ 1 Department of Physiology and Biophysics, School of Medicine, Case Western Reserve University, Cleveland, \\ OH 44106, USA; pdcabral@gmail.com (P.D.C.); nxh156@case.edu (N.J.H.); jaa122@case.edu (J.A.); \\ nxy66@case.edu (N.Y.); jessica.berthiaume@case.edu (J.M.B.); jlg5@case.edu (J.L.G.) \\ 2 Facultad de Farmacia y Bioquímica, Universidad de Buenos Aires, Ciudad Autónoma de Buenos Aires C1113AAD, \\ Argentina; dominici@qb.ffyb.uba.ar \\ 3 Facultad de Medicina, Departamento de Ciencias Fisiológicas, Universidad de Buenos Aires, \\ Ciudad Autónoma de Buenos Aires C1121ABG, Argentina \\ 4 Current Address: Miromatrix Medical Inc., 10399 W 70th St, Eden Prairie, MN 55344, USA \\ 5 Instituto de Química y Fisicoquímica Biológicas, CONICET, Ciudad Autónoma de Buenos Aires C1113AAD, Argentina \\ * Correspondence: agustin.gonzalezvicente@case.edu; Tel.: +1-(216)-368-1687
}

Received: 28 June 2017; Accepted: 11 August 2017; Published: 16 August 2017

\begin{abstract}
Fructose-enriched diets cause salt-sensitive hypertension. Proximal tubules (PTs) reabsorb $70 \%$ of the water and salt filtered through the glomerulus. Angiotensin II (Ang II) regulates this process. Normally, dietary salt reduces Ang II allowing the kidney to excrete more salt, thereby preventing hypertension. We hypothesized that fructose-enriched diets enhance the ability of low concentrations of Ang II to stimulate PT transport. We measured the effects of a low concentration of Ang II $\left(10^{-12} \mathrm{~mol} / \mathrm{L}\right)$ on transport-related oxygen consumption $\left(\mathrm{QO}_{2}\right)$, and $\mathrm{Na} / \mathrm{K}$-ATPase and $\mathrm{Na} / \mathrm{H}$-exchange (NHE) activities and expression in PTs from rats consuming tap water (Control) or $20 \%$ fructose (FRUC). In FRUC-treated PTs, Ang II increased $\mathrm{QO}_{2}$ by $14.9 \pm 1.3 \mathrm{nmol} / \mathrm{mg} / \mathrm{min}$ $(p<0.01)$ but had no effect in Controls. FRUC elevated NHE3 expression by $19 \pm 3 \%(p<0.004)$ but not Na/K-ATPase expression. Ang II stimulated NHE activity in FRUC PT $(\Delta+0.7 \pm 0.1$ Arbitrary Fluorescent units (AFU)/s, $p<0.01$ ) but not in Controls. Na/K-ATPase activity was not affected. The PKC inhibitor Gö6976 blocked the ability of FRUC to augment the actions of Ang II. FRUC did not alter the inhibitory effect of dopamine on NHE activity. We conclude that dietary fructose increases the ability of low concentrations of Ang II to stimulate PT Na reabsorption via effects on NHE.
\end{abstract}

Keywords: kidney; hypertension; sodium transport; salt sensitivity

\section{Introduction}

Consumption of fructose has increased dramatically in the past three decades due to addition of low-cost high-fructose corn syrup to processed foods and sugar-sweetened beverages. In European countries and the United States, calories ingested from fructose follow a normal distribution with a mean of approximately $10 \%$ of the daily caloric intake coming from this sugar [1-3]. This not only reduces the quality of the diet [4] but sets the second quartile at risk of ingesting at least $20 \%$ of the calories as fructose [1-3], primarily as sugar-sweetened beverages [3,5]. Dietary fructose causes hypertension and cardiovascular disease in humans [6-13]. It also causes hypertension in rats fed comparable amounts of fructose to those consumed by people [14-16]. The increases in blood pressure occur even when plasma insulin, glucose and/or lipids are within normal ranges $[14,17,18]$. 
Hypertension cannot be sustained without a renal defect or pressure natriuresis would return blood pressure to normal values. Defects in proximal tubule transport or its regulation result in changes in blood pressure $[19,20]$. In this segment, most of the Na enters the cells in exchange for protons by the apical $\mathrm{Na} / \mathrm{H}$ exchanger type 3 (NHE3) while the remainder drives sugar, amino acid and phosphate uptake via other specific transporters. Exit of $\mathrm{Na}$ from the cells into the blood is mediated by $\mathrm{Na} / \mathrm{K}$-ATPase.

Ang II is a key regulator of blood pressure primarily via actions on the kidney in general [21], and the proximal tubule specifically [22]. These effects are mostly mediated via Ang II type 1 receptors (AT1R) [22] followed by activation of protein kinase C (PKC) [23-26]. AT1R antagonists ameliorate hypertension in the fructose-fed rat [27-30], indicating that Ang II signaling is involved in the pathology of this model. We previously reported that acute exposure of proximal tubules to fructose enhances the ability of a low concentration of Ang II $\left(10^{-12} \mathrm{~mol} / \mathrm{L}\right)$ to elevate NHE activity [16]. Such low concentrations of Ang II had no effect in the absence of fructose or in the presence of an equimolar concentration of glucose [16]. However, the effects of dietary fructose on the actions of Ang II in the proximal tubule remain to be elucidated.

The proximal tubule displays a biphasic response to Ang II. Concentrations ranging from $10^{-12}$ to $10^{-10} \mathrm{~mol} / \mathrm{L}$ progressively stimulate transport, while concentrations greater than $10^{-8} \mathrm{~mol} / \mathrm{L}$ inhibit it [31,32]. Even though renal cortical Ang II levels are not precisely known, proximal tubule $\mathrm{Na}$ reabsorption is stimulated by normal physiological concentrations of Ang II when animals are on a normal-salt diet [21,33]. Experiments comparing the effects of Ang II infusion on Na retention in salt-restricted vs. salt-loaded rats indicate that Ang II levels maximally stimulate Na reabsorption in rats consuming reduced-salt diets [34,35]. Taken together, these data indicate that, in rats fed normal salt, renal cortical Ang II likely range from $10^{-11} \mathrm{~mol} / \mathrm{L}$ [36,37] to $10^{-10} \mathrm{~mol} / \mathrm{L}$ [38-41].

When animals consume excess dietary salt systemic Ang II levels fall by about an order of magnitude [42]. Thus, plasma Ang II concentrations are around $10^{-12} \mathrm{~mol} / \mathrm{L}$ when rats are fed high salt. Reductions in renal Ang II allow increased urinary Na excretion (UNaV), and thereby elimination of excess salt. If this process is blocked, salt is retained and an elevation in blood pressure is required to restore Na balance causing salt-sensitive hypertension [43,44].

Salt sensitivity of blood pressure in rodents eating fructose-enriched diets is well documented [13,16,45-47]. In a previous study, we have shown that rats consuming $20 \%$ fructose remain normotensive at least two weeks while on normal salt, but addition of $4 \%$ salt to the diet produces an immediate increase in blood pressure [16]. Consistently, salt restriction prevents the development of hypertension in Sprague Dawley rats given fructose-containing diets ranging from $20 \%$ in the drinking water to $66 \%$ in the chow $[13,16,46]$. Such data indicate that fructose interferes with salt excretion mechanisms. Given that downregulation of the renin/angiotensin system is one of the primary mechanisms by which excretion of excess salt occurs, we designed this study to evaluate whether dietary fructose increases the ability of low concentrations of Ang II to stimulate proximal tubule Na transport.

We hypothesized that $20 \%$ fructose in drinking water enhances the ability of $10^{-12} \mathrm{~mol} / \mathrm{L}$ Ang II to stimulate proximal tubule Na reabsorption, and that this is due to activation of PKC and NHE rather than $\mathrm{Na} / \mathrm{K}$-ATPase activity.

\section{Materials and Methods}

Drugs and Buffers: Unless specified, all drugs and reagents were obtained from Sigma-Aldrich (St. Louis, MO, USA). The composition of all solutions used in this study is shown in Table 1. Bicarbonate-Buffered Physiological Saline was continuously bubbled at $37{ }^{\circ} \mathrm{C}$ with $95 \% \mathrm{O}_{2} / 5 \% \mathrm{CO}_{2}$. Osmolality was titrated with mannitol to $300 \mathrm{mOsmol} / \mathrm{L}$. In HEPES-Buffered Physiological Saline, Acid Pulse Buffer and K-Free HEPES-Buffered Solution, the $\mathrm{pH}$ was titrated to 7.5 with $\mathrm{NaOH}$ and osmolality to $300 \mathrm{mOsmol} / \mathrm{L}$ with mannitol. The $4 \mathrm{X}$ Reaction Media, and the 4X Reaction Media with Ouabain contained $6 \mathrm{U} / \mathrm{mL}$ of Pyruvate Kinase (PK) and $9 \mathrm{U} / \mathrm{mL}$ Lactic Dehydrogenase (LDH). 
The PK/LDH enzyme mix (Sigma, St. Louis, MO, USA, P0294) was also source of $1 \mathrm{mmol} / \mathrm{L}$ $\mathrm{KCl}$. Both solutions contained $0.1 \%$ of dimethyl sulfoxide (DMSO) used as an ouabain carrier. The $\mathrm{pH}$-sensitive fluorescent dye 2',7'-bis-(2-carboxyethyl)-5-(and-6)-carboxyfluorescein acetoxymethyl ester (BCECF-AM; Molecular Probes, Eugene, OR, USA) was dissolved daily in anhydrous DMSO and diluted in HEPES-Buffered Physiological Saline to reach a final concentration of $1 \mu \mathrm{mol} / \mathrm{L}$.

Table 1. Solutions and Buffers.

\begin{tabular}{|c|c|c|c|c|c|c|c|}
\hline & & $\begin{array}{l}\text { Bicarbonate- } \\
\text { Buffered } \\
\text { Physiological } \\
\text { Saline }\end{array}$ & $\begin{array}{c}\text { HEPES- } \\
\text { Buffered } \\
\text { Physiological } \\
\text { Saline }\end{array}$ & $\begin{array}{c}\text { K-Free } \\
\text { HEPES-Buffered } \\
\text { Solution }\end{array}$ & $\begin{array}{l}\text { Acid Pulse } \\
\text { Buffer }\end{array}$ & $\begin{array}{l}\text { 4X Reaction } \\
\text { Media }\end{array}$ & $\begin{array}{c}\text { 4X Reaction } \\
\text { Media with } \\
\text { Ouabain }\end{array}$ \\
\hline $\mathrm{NaHCO}_{3}$ & $(\mathrm{mmol} / \mathrm{L})$ & 25.0 & - & - & - & - & - \\
\hline HEPES & $"$ & - & 10.0 & 10.0 & 10.0 & - & - \\
\hline Imidazole & $"$ & - & - & - & - & 200.0 & 200.0 \\
\hline $\mathrm{NaCl}$ & $"$ & 114.0 & 130.0 & 130.0 & 120.0 & 320.0 & 320.0 \\
\hline $\mathrm{KCl}$ & $"$ & 4.0 & 4.0 & - & 4.0 & 120.0 & - \\
\hline $\mathrm{Na}_{2} \mathrm{HPO}_{4}$ & $"$ & 2.1 & 2.5 & 2.5 & 2.5 & - & - \\
\hline $\mathrm{NaH}_{2} \mathrm{PO}_{4}$ & $"$ & 0.4 & - & - & - & - & - \\
\hline $\mathrm{Mg} \mathrm{SO}_{4}$ & $"$ & 1.2 & 1.2 & 1.2 & 1.2 & 20.0 & 20.0 \\
\hline $\mathrm{Ca}(\text { Lactate })_{2}$ & $"$ & 2.0 & 2.0 & 2.0 & 2.0 & - & - \\
\hline $\mathrm{Na}_{3}$ Citrate & $"$ & 1.0 & 1.0 & 1.0 & 1.0 & - & - \\
\hline DL-alanine & $"$ & 6.0 & 6.0 & 6.0 & 6.0 & - & - \\
\hline Glucose & $"$ & 5.5 & 5.5 & 5.5 & 5.5 & - & - \\
\hline $\mathrm{NH}_{4} \mathrm{Cl}$ & $"$ & - & - & - & 10.0 & - & - \\
\hline EGTA & $"$ & - & - & - & - & 2.0 & 2.0 \\
\hline $\mathrm{Na}_{2} \mathrm{ATP}$ & $"$ & - & - & - & - & 20.0 & 20.0 \\
\hline NADH & $"$ & - & - & - & - & 4.0 & 4.0 \\
\hline $\begin{array}{c}\text { Ascorbic } \\
\text { Acid }\end{array}$ & $"$ & - & - & - & - & 4.0 & 4.0 \\
\hline PEP & $"$ & - & - & - & - & 40.0 & 40.0 \\
\hline
\end{tabular}

Animals: This study was approved by the Case Western Reserve University Institutional Animal Care and Use Committee. All experiments were conducted in accordance with the National Institutes of Health Guidelines for the Care and Use of Laboratory Animals. Male Sprague Dawley rats (Charles River Breeding Laboratories, Wilmington, MA, USA) weighing 130 g were used in all protocols. All efforts were made to minimize stress and discomfort.

Protocol 1: To measure blood pressure and run a metabolic panel, 11 animals were randomly divided into 2 dietary treatments: (1) the Control which drank water purified with a Milli-Q system (Millipore Sigma, Billerica, MA, USA); and (2) FRUC which drank a 20\% fructose solution. Both groups received an artificial purified diet (TestDiet, St. Louis, MO, USA, \#5876) containing $\sim 100 \mathrm{meq} / \mathrm{kg}$ of $\mathrm{Na}(0.61 \%$ if expressed as $\mathrm{NaCl})$. Animals were allowed to acclimate to the facility and the diet for 4-7 days while drinking tap water. After the acclimation period animals were randomly split and assigned to either FRUC or Control groups (Day 0). From Day 6 to Day 7, animals were housed individually, to measure food and water consumption every $24 \mathrm{~h}$. Final weight and blood pressure were also measured. At Day 8, animals were anesthetized with isoflurane using $100 \% \mathrm{O}_{2}$ as a carrier and underwent terminal surgery. Blood was drawn from the thoracic aorta using a 20 Gauge needle on a $10 \mathrm{~mL}$ heparinized syringe. Immediately after collection $\mathrm{pH}, \mathrm{Na}, \mathrm{K}, \mathrm{Cl}$ and Lactate were measured using a Nova Prime Blood Analyzer (Nova Biomedicals, Walthman, MA, USA). The remainder of the blood was centrifuged for collection of plasma. Plasma was aliquoted and frozen for insulin measurements. Insulin was determined using a Rat Insulin ELISA kit (MERCODIA AB, Uppsala, Sweden) according to manufacturer recommendations.

Protocol 2: For all studies involving tubule dissection or suspensions, animals received regular rat chow ( $100 \mathrm{meq} / \mathrm{kg} \mathrm{Na}$ ), and either: (1) tap water; or (2) 20\% fructose in drinking water (FRUC). After 7-9 days of dietary treatment, the animals were anesthetized with ketamine (100 mg/kg bw IP) and xylazine (20 mg/kg bw IP), and given 2 IU heparin (IP). Only one sample, either a proximal tubules suspension or a microdissected proximal tubule was obtained per animal. 
Proximal Tubule Suspensions: Proximal tubule suspensions were generated using methods similar to those we used before [48]. Briefly, rats were anesthetized and an abdominal u-shaped incision was made. The kidneys were retro-perfused from the abdominal aorta with $80 \mathrm{~mL}$ of Bicarbonate-Buffered Physiological Saline at $37^{\circ} \mathrm{C}$ containing $1 \mathrm{mg} / \mathrm{mL}$ collagenase and $2 \mathrm{U} / \mathrm{mL}$ heparin at $0.7 \mathrm{~mL} / \mathrm{min}$.

Immediately after perfusion the kidneys were excised and rapidly cooled by immersion in Bicarbonate-Buffered Physiological Saline at $4{ }^{\circ} \mathrm{C}$. The cortex of each kidney was gently scraped with a blade, minced and transferred to a $5 \mathrm{~mL}$ conical tube. Tissue was disrupted by passing it through a pipette tip and stirring on ice for $5 \mathrm{~min}$. The resulting suspension was filtered through a $390 \mu \mathrm{m}$ mesh, and the tubules recovered by centrifugation at $4{ }^{\circ} \mathrm{C}(100 \times g$ for $2 \mathrm{~min})$. The tubules were rinsed, filtered through a $250 \mu \mathrm{m}$ mesh, and recovered by centrifugation at $4{ }^{\circ} \mathrm{C}(80 \times g$ for $2 \mathrm{~min})$. The final pellet was resuspended in 5-10 mL of warm, gassed Bicarbonate-Buffered Physiological Saline. After sitting for $1 \mathrm{~min}$ to sediment glomeruli, $3 \mathrm{~mL}$ of the upper suspension were taken for experiments.

Oxygen Consumption: $\mathrm{QO}_{2}$ was measured using methods similar to those we reported [49]. Briefly, 2 to $4 \mathrm{mg}$ of protein from proximal tubule suspensions were taken to a final volume of $6 \mathrm{~mL}$ in the chamber of a YSI Model 5301B bath assembly (Yellow Springs Instruments, Yellow Springs, OH, USA). The chamber was equilibrated at $37{ }^{\circ} \mathrm{C}$ with a gas mix containing $95 \% \mathrm{O}_{2} / 5 \% \mathrm{CO}_{2}$ and then closed. The oxygen tension in the chamber was monitored using a YSI Model 5300 Biological Oxygen Monitor (Yellow Springs Instruments) attached to a PowerLab (ADInstruments, Colorado Springs, CO, USA). After stabilization of about $90 \mathrm{~s}$, basal $\mathrm{QO}_{2}$ was recorded for $1 \mathrm{~min}$, and $10^{-12} \mathrm{~mol} / \mathrm{L}$ Ang II was added while $\mathrm{QO}_{2}$ was continuously measured. At the end of the experiment tubules were recovered by centrifugation to determine protein content. The results were expressed as nmol $\mathrm{O}_{2} / \mathrm{mg}$ protein/min.

Western Blotting: Western blotting of fresh samples was conducted using similar techniques as before [50]. In brief, proximal tubule suspensions were dissolved in lysis buffer (Sigma, CelLytic ${ }^{\mathrm{TM}}$ ) containing 1\% protease inhibitor cocktail (Sigma, P8340). Lysed samples rested for at least 5 min on ice and debris was removed by centrifugation $\left(5600 \times g, 5 \mathrm{~min}, 4^{\circ} \mathrm{C}\right)$. Protein content was determined by a colorimetric assay. Samples were loaded onto $6 \%$ polyacrylamide gels, loading equal amounts of protein on each lane. Samples from FRUC and Control were processed in pairs and loaded on the same gel, so each gel had its own control. Electrophoresis was performed at $100 \mathrm{~V}$ and proteins transferred to a 0.45 micron PVDF (polyvinylidene difluoride) membrane (Bio-RAD, Hercules CA, USA) overnight. After transferring, membranes were cut at about $60 \mathrm{kD}$. The upper membranes were blotted for either Na/K-ATPase $\alpha 1$-subunit or NHE3, while the lower parts were blotted for either $\beta$-tubulin or glyceraldehydephosphate dehydrogenase (GAPDH) as loading controls, respectively. Western blots were conducted as specified in Table 2. All incubations were at room temperature. No membrane was stripped.

Table 2. Antibodies and Blotting Conditions.

\begin{tabular}{|c|c|c|c|c|c|c|c|}
\hline \multirow{2}{*}{ Antibody } & \multirow{2}{*}{ Provider } & \multirow{2}{*}{$\begin{array}{l}\text { Catalog } \\
\text { Number }\end{array}$} & \multirow{2}{*}{ Source } & \multirow{2}{*}{$\begin{array}{c}\text { Blocking } \\
\text { Buffer }\end{array}$} & \multicolumn{3}{|c|}{ Conditions } \\
\hline & & & & & Dilution & Buffer & Time \\
\hline NHE3 & Abcam & ab95299 & Rabbit & $5 \%$ BSA & $1: 1000$ & $5 \%$ BSA & $2 \mathrm{~h}$ \\
\hline$\alpha 1-\mathrm{Na} / \mathrm{K}-\mathrm{ATPase}$ & Cell Signaling & \#3010 & Rabbit & 5\% Milk & $1: 5000$ & 5\% Milk & $2 \mathrm{~h}$ \\
\hline$\beta$-tubulin & Abcam & ab6046 & Rabbit & 5\% Milk & $1: 10,000$ & 5\% Milk & $2 \mathrm{~h}$ \\
\hline GAPDH-HRP & Abcam & ab9485 & - & $5 \%$ BSA & $1: 15,000$ & $5 \%$ BSA & $2 \mathrm{~h}$ \\
\hline 2ry anti-Rabbit-HRP & GE Healthcare & NA9340V & Donkey & - & $1: 2500$ & $5 \%$ BSA & $1 \mathrm{~h}$ \\
\hline
\end{tabular}

${ }^{*}$ BSA: Bovine Serum Albumin, Milk: non-fat dehydrated bovine milk.

Protein Detection and Densitometry: Membranes were incubated with Luminta ${ }^{\mathrm{TM}} \mathrm{Classico}$ Western HRP Substrate (Millipore, Billerica, MA, USA) and the signal detected by exposing a HyBlot CL (Denver Scientific, Holliston, MA, USA) autoradiography film to the membranes. Films were scanned in a single session using an EPSON Expression 1680 scanner with EPSON-Scan software (Settings: positive film, 16-bit greyscale, $600 \mathrm{dpi}$ ) and densitometry measured using Image J 1.47p 
software. After densitometry, the average peak-area of all experimental lanes in each membrane was calculated and the peak-areas of individual lanes were expressed as a fraction of this value. Results were expressed as Na/K-ATPase/ $\beta$-tubulin ratio and as NHE3/GAPDH ratio.

$\mathrm{Na} / \mathrm{K}$-ATPase activity: The hydrolytic activity of the Na/K-ATPase was measured by coupling ADP production to 2 enzymatic reactions which produce NAD+, similar to what we have done before [51]. Briefly, an aliquot of proximal tubule suspension was rinsed with K-Free HEPES-Buffered Solution and placed on an inverted microscope. Using micro tweezers, 2 tubules totaling not less than $0.5 \mathrm{~mm}$ were transferred to a $0.5 \mathrm{~mL}$ "safe-lock"-Eppendorf tube containing $30 \mu \mathrm{L}$ of $0.7 \%$ octyl glucoside (Sigma-\#30887) and either vehicle or Ang II. Tubules were incubated on ice between 10 and $15 \mathrm{~min}$, and then $13 \mu \mathrm{L}$ of $4 \mathrm{X}$ Reaction Media were added to all tubes but the ouabain ones which received $4 \mathrm{X}$ Reaction Media with Ouabain. Samples were incubated at $37^{\circ} \mathrm{C}$ for $30 \mathrm{~min}$. The reaction was stopped by adding $53 \mu \mathrm{L}$ of $0.5 \mathrm{~mol} / \mathrm{L} \mathrm{HCl}$ to each tube and then incubating the mix for $15 \mathrm{~min}$ at $37^{\circ} \mathrm{C}$. Finally, the whole reaction volume was transferred to a $2 \mathrm{~mL}$ Eppendorf tube containing $1 \mathrm{~mL}$ of $6 \mathrm{~mol} / \mathrm{L} \mathrm{KOH}$ and incubated at $60^{\circ} \mathrm{C}$ for $20 \mathrm{~min}$ in the dark. All samples were measured on a Hitachi F2700 spectrofluorometer, exciting at $366 \mathrm{~nm}$ and collecting light at $455 \mathrm{~nm}$. A calibration curve was obtained by adding 0.5 to $3 \mathrm{nmol}$ of ADP to different tubes, which were processed under the same conditions as the samples. Linear regression of the data provided a slope used to calibrate the assay. $\mathrm{Na} / \mathrm{K}-\mathrm{ATPase}$ activity was expressed as $\mathrm{pmol} \mathrm{ATP} / \mathrm{mm} / \mathrm{min}$.

Isolation of Proximal Tubules: The abdominal cavity was opened and the left kidney bathed in ice-cold $150 \mathrm{mmol} / \mathrm{L} \mathrm{NaCl}$. The kidney was removed and placed in ice-cold HEPES-Buffered Physiological Saline at $4{ }^{\circ} \mathrm{C}$. Coronal slices were cut and proximal tubules were isolated from the cortex using microforceps under a stereomicroscope at 4 to $10^{\circ} \mathrm{C}$. Tubular segments ranging from 0.7 to $1.0 \mathrm{~mm}$ were then transferred to a temperature-regulated chamber and perfused using concentric glass pipettes at $37 \pm 1{ }^{\circ} \mathrm{C}$ as we have previously described [16,50].

Measurement of NHE Activity Using the $\mathrm{NH}_{4} \mathrm{Cl}$ Acid Pulse: The intracellular fluorescence detection system was set up on a Nikon Diaphot inverted microscope (Nikon, Japan). Proximal tubules were loaded with $1 \mu \mathrm{M}$ BCECF-AM in the basolateral bath at $37 \pm 1{ }^{\circ} \mathrm{C}$ for $5 \mathrm{~min}$ and then washed for $10 \mathrm{~min}$ in dye-free HEPES-Buffered Physiological Saline. BCECF was excited alternately at 490 and $450 \mathrm{~nm}$ and emitted fluorescence measured using a $510 \mathrm{~nm}$ dichroic mirror. Fluorescent images were taken utilizing a 40X oil immersion objective and a Coolsnap HQ digital camera (Photometrics, Tucson, AZ, USA), and ratiometric measurements (490/450) were recorded using Metafluor version 7 imaging software (Universal Imaging, Downington, PA, USA).

After the dye-free washing period measurements were taken once every $2 \mathrm{~s}$ for $1 \mathrm{~min}$. The basolateral bath solution was then switched to the Acid Pulse Buffer. After $20 \mathrm{~s}$, the basolateral bath was exchanged back to HEPES-Buffered Physiological Saline. This procedure causes an initial intracellular alkalinization followed by intracellular acidification. The initial rate of intracellular $\mathrm{pH}$ recovery that follows was taken as a measurement of NHE activity and quantified as fluorescent units per s (AFU/s). Different compounds of interest were then added to the basolateral bath as indicated in the Results section. After a 10 min re-equilibration period, the $\mathrm{NH}_{4} \mathrm{Cl}$ acid pulse was repeated. The recovery rates in both periods were compared.

Systolic Blood Pressure: Blood pressure was measured non-invasively in conscious animals using the CODA tail-cuff blood pressure system (Kent Scientific, Torrington, CT, USA). Animals were trained on Days 0, 2 and 4 of the dietary treatment and the final measurement was taken at 9:00 a.m. on Day 7 .

Statistics: All data were analyzed using R, version 3.2.3 (R Foundation for Statistical Computing, Vienna, Austria. URL https:/ /www.R-project.org/). Means were compared using unpaired 2-tailed Student t-tests. All $p$ values $<0.05$ were considered significant. Results are expressed as the arithmetic mean \pm the standard error of the mean of each group, or by the difference between two means \pm the standard error of that difference. 


\section{Results}

A metabolic panel of this model is presented in Table 3. Animals on both diets gained weight at the same rate and ingested similar calories. However, the FRUC group ate $\sim 30 \%$ less food. There were no differences in weight or systolic blood pressure after seven days of treatment. Fructose feeding did not affect the main electrolytes $\mathrm{Na}, \mathrm{K}$ and $\mathrm{Cl}$, nor the acid-base balance as measured by lactate and $\mathrm{pH}$. Insulin levels of both groups were within normal range. Together, these data indicate that consumption of $20 \%$ fructose in the drinking water for seven days does not cause metabolic syndrome.

Table 3. Metabolic Panel.

\begin{tabular}{|c|c|c|c|c|c|c|c|}
\hline & & \multicolumn{2}{|c|}{ Control $(n=5)$} & \multicolumn{2}{|c|}{ Fructose $(n=6)$} & \multirow{2}{*}{ Change } & \multirow{2}{*}{$T$ test } \\
\hline & & Mean & SEM & Mean & SEM & & \\
\hline Caloric Intake & (kcal/24 h) & 69.9 & 6.0 & 65.5 & 3.2 & $=$ & $p<0.51$ \\
\hline Weight Gain & (g/24 h) & 9.4 & 1.3 & 9.2 & 2.4 & $=$ & $p<0.94$ \\
\hline Fluid Intake & $(\mathrm{mL} / 24 \mathrm{~h})$ & 29.2 & 4.6 & 25.8 & 3.1 & $=$ & $p<0.55$ \\
\hline Food Intake & $(g / 24 \mathrm{~h})$ & 17.4 & 1.5 & 12.0 & 0.5 & $\downarrow$ & $p<0.01$ \\
\hline Final Weight & (g) & 236 & 7 & 232 & 10 & $=$ & $p<0.72$ \\
\hline \multirow[t]{3}{*}{ Systolic BP } & $(\mathrm{mmHg})$ & 130 & 11 & 147 & 6 & $=$ & $p<0.18$ \\
\hline & & \multicolumn{2}{|c|}{ Control } & \multicolumn{2}{|c|}{ Fructose } & \multirow{2}{*}{ Change } & \multirow{2}{*}{$\mathrm{T}$ test } \\
\hline & & Mean & SEM & Mean & SEM & & \\
\hline $\mathrm{pH}$ & & 7.42 & 0.01 & 7.38 & 0.03 & $=$ & $p<0.18$ \\
\hline $\mathrm{Na}$ & $(\mathrm{mmol} / \mathrm{L})$ & 136.6 & 0.6 & 137.5 & 0.5 & $=$ & $p<0.31$ \\
\hline $\mathbf{K}$ & $(\mathrm{mmol} / \mathrm{L})$ & 3.8 & 0.2 & 3.7 & 0.1 & $=$ & $p<0.73$ \\
\hline $\mathrm{Cl}$ & $(\mathrm{mmol} / \mathrm{L})$ & 106.4 & 0.5 & 106.0 & 0.3 & $=$ & $p<0.55$ \\
\hline Lactate & $(\mathrm{mmol} / \mathrm{L})$ & 1.02 & 0.14 & 1.03 & 0.07 & $=$ & $p<0.98$ \\
\hline Insulin & $(\mu \mathrm{g} / \mathrm{mL})$ & 0.38 & 0.14 & 0.36 & 0.15 & $=$ & $p<0.93$ \\
\hline
\end{tabular}

We started testing our hypothesis by studying whether a low concentration of Ang II affects transport in proximal tubules suspensions. We found that Ang II $\left(10^{-12} \mathrm{~mol} / \mathrm{L}\right)$ stimulated $\mathrm{QO}_{2}$ by $14.9 \pm 3 \mathrm{nmol} / \mathrm{mg} / \mathrm{min}(p<0.01, n=12)$ in suspensions from FRUC. In contrast, $\mathrm{QO}_{2}$ was $96 \pm 4 \mathrm{nmol} / \mathrm{mg} / \mathrm{min}$ before Ang II and $99 \pm 6 \mathrm{nmol} / \mathrm{mg} / \mathrm{min}$ afterwards in Control suspensions (Figure 1). Thus, although basal transport rates were similar in both groups, Ang II ( $\left.10^{-12} \mathrm{~mol} / \mathrm{L}\right)$ only enhanced $\mathrm{QO}_{2}$ in suspensions from the rats on the fructose diet. To show that the lack of an effect of $10^{-12}$ Ang II in control suspensions was not due to a complete inability to respond to Ang II, we tested $10^{-9}$ Ang II and found no difference between groups in total $\mathrm{QO}_{2}$ (FRUC $116 \pm 5 \mathrm{nmol} / \mathrm{mg} / \mathrm{min}$ vs. $115 \pm 7 \mathrm{nmol} / \mathrm{mg} / \mathrm{min}$ in Control; $n=12$ ).

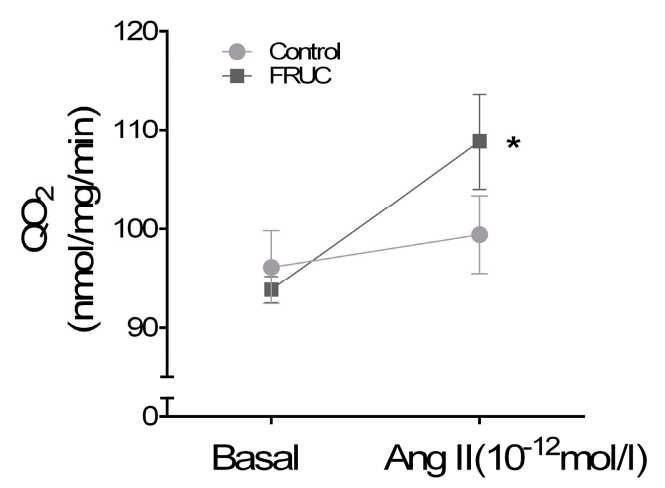

Figure 1. Effect of $10^{-12} \mathrm{~mol} / \mathrm{L}$ Ang II on $\mathrm{QO}_{2}$ in proximal tubule suspensions from rats consuming either $20 \%$ fructose (FRUC) or tap water (Control). Ang II stimulated $\mathrm{QO}_{2}$ in FRUC $(n=12)$ but not in Controls $(n=12)$. In FRUC, * indicates $p<0.01$ for $10^{-12} \mathrm{~mol} / \mathrm{L}$ Ang II vs. basal. 
Transport rates are determined in part by transporters' abundance. Thus, we assessed protein levels of the two main $\mathrm{Na}$ transporters in proximal tubules, the $\alpha 1$ subunit of $\mathrm{Na} / \mathrm{K}$-ATPase and NHE3 by Western blots. We found no difference in the $\alpha 1$-subunit/ $\beta$-tubulin ratio of tubules from the two dietary groups $(1.06 \pm 0.1$ vs. $0.97 \pm 0.10$; Figure $2 \mathrm{~A})$. In contrast, we found that the NHE3/GAPDH optical density ratio was $1.10 \pm 0.03$ in tubules from FRUC and $0.90 \pm 0.03$ in controls $(\Delta+19 \pm 3 \%$; $p<0.004$; Figure 2B).

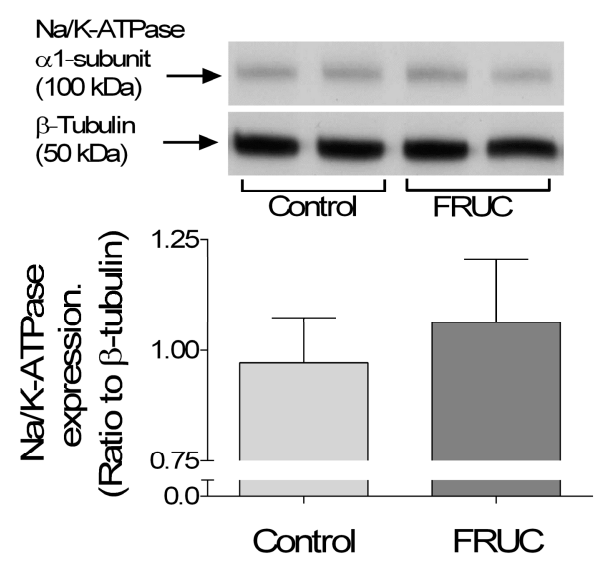

(A)

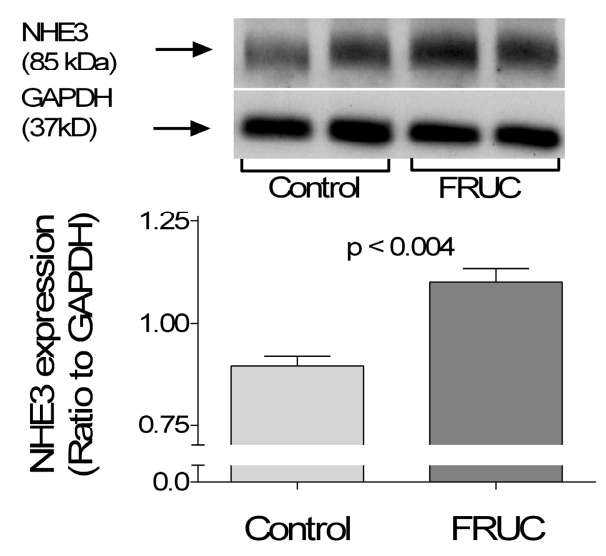

(B)

Figure 2. Effect of drinking $20 \%$ fructose (FRUC) or tap water (Control) on the expression of: (A) Na/K-ATPase; and (B) NHE3 in proximal tubule suspensions, as measured by Western blots. Results are relative to $\beta$-tubulin and GAPDH, respectively.

To assess intrinsic changes in transporter function, we measured Na/K-ATPase and NHE3 activities. Na/K-ATPase was assessed by the ATP hydrolytic activity of permeabilized tubules, where $\mathrm{Na}$ gradients secondary to enhanced apical entry are negligible. Under these conditions, Ang II $\left(10^{-12} \mathrm{~mol} / \mathrm{L}\right)$ did not significantly enhance $\mathrm{Na} / \mathrm{K}$-ATPase activity in tubules from either group (Figure 3). In FRUC tubules, Na/K-ATPase was $35 \pm 11 \mathrm{pmol} \mathrm{ATP} / \mathrm{mm} / \mathrm{min}$ without Ang II and $39 \pm 11 \mathrm{pmol}$ ATP $/ \mathrm{mm} / \mathrm{min}$ with Ang II $(n=7)$. In controls, the values were $44 \pm 7 \mathrm{pmol}$ $\mathrm{ATP} / \mathrm{mm} / \mathrm{min}$ without Ang II and $48 \pm 4 \mathrm{pmol} \mathrm{ATP} / \mathrm{mm} / \mathrm{min}$ with Ang II $(n=7)$. Ang II $\left(10^{-9} \mathrm{~mol} / \mathrm{L}\right)$ used as a positive control stimulated $\mathrm{Na} / \mathrm{K}$-ATPase activity to the same extent in tubules from both groups $(63 \pm 15 \mathrm{pmol}$ ATP $/ \mathrm{mm} / \mathrm{min}$ in FRUC vs. $70 \pm 9 \mathrm{pmol}$ ATP $/ \mathrm{mm} / \mathrm{min}$ in controls; $n=7$ ). These results show that Na/K-ATPase is not affected by dietary fructose. 


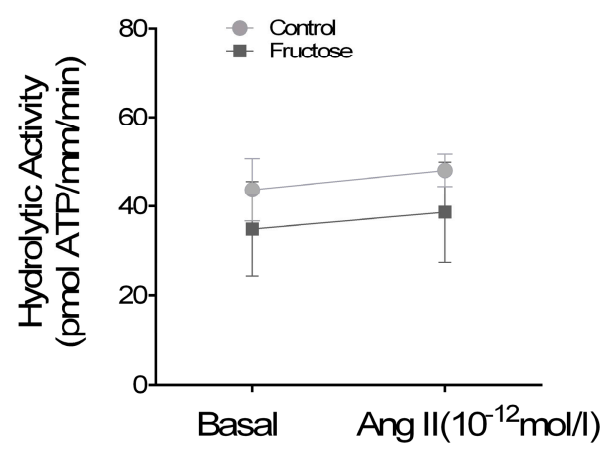

Figure 3. Effect of $10^{-12} \mathrm{~mol} / \mathrm{L}$ Ang II on $\mathrm{Na} / \mathrm{K}$-ATPase hydrolytic activity, in permeabilized proximal tubule from rats consuming either $20 \%$ fructose (FRUC) or tap water (Control).

NHE3 activity was assessed by $\mathrm{pH}$ recovery in isolated perfused proximal tubules. Addition of $10^{-12} \mathrm{~mol} / \mathrm{L}$ Ang II had no significant effect on $\mathrm{pH}$ recovery in Control tubules which recovered at a rate of $2.0 \pm 0.2$ arbitrary fluorescent units (AFU) /s without and at $1.8 \pm 0.1$ with $10^{-12} \mathrm{~mol} / \mathrm{L}$ Ang II $(\Delta-0.2 \pm 0.2 \mathrm{AFU} / \mathrm{s})$. In the FRUC tubules, Ang II increased recovery by $0.7 \pm 0.1 \mathrm{AFU} / \mathrm{s}(p<0.01$; $n=5$; Figure 4 ). These results show that a low concentration of Ang II only stimulated NHE in tubules from rats receiving fructose in the drinking water.

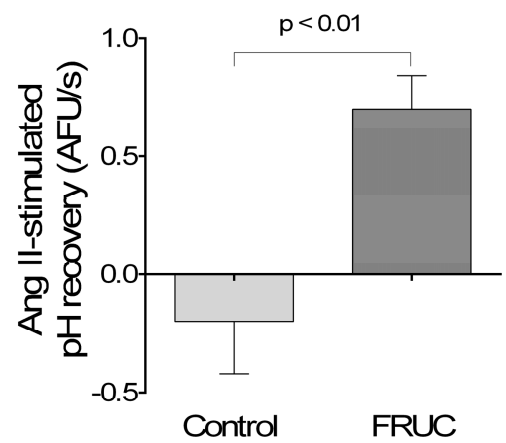

Figure 4. Effect of $10^{-12} \mathrm{~mol} / \mathrm{L}$ Ang II on $\mathrm{pH}$ recovery after an $\mathrm{NH}_{4}$ pulse in proximal tubules isolated from rats consuming either $20 \%$ fructose (FRUC) or tap water (Control).

We next studied whether changes in Ang II signaling could be affecting NHE3 activity. When PKC $\alpha / \beta 1$ were inhibited, the $\mathrm{pH}$ recovery rate in the presence of Ang II $\left(10^{-12} \mathrm{~mol} / \mathrm{L}\right)$ in tubules from animals on fructose was $1.2 \pm 0.2 \mathrm{AFU} / \mathrm{s}$, not different from the $1.9 \pm 0.6 \mathrm{AFU} / \mathrm{s}$ in its absence $(n=5$; Figure 5). These data indicate that, upon PKC $\alpha / \beta 1$ inhibition, FRUC tubules lack the ability to increase $\mathrm{pH}$ recovery in response to $10^{-12} \mathrm{~mol} / \mathrm{L}$ Ang II. This concentration of Ang II has no effect on pH recovery in controls (Figure 4).

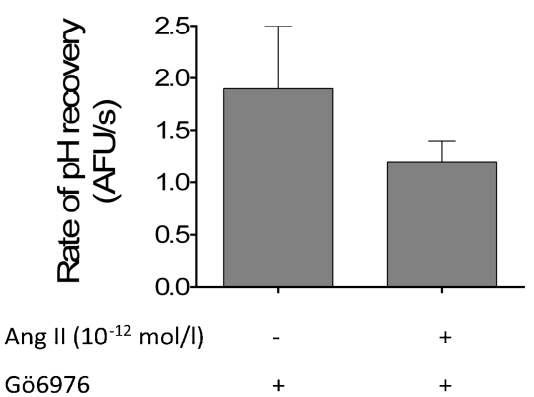

Figure 5. Effect of $10^{-12} \mathrm{~mol} / \mathrm{L}$ Ang II on $\mathrm{pH}$ recovery after an $\mathrm{NH}_{4}$ pulse in the presence of the PKC inhibitor Gö6976 in proximal tubules from rats consuming 20\% fructose. 
Impairment of inhibitory signals could be augmenting a positive response to Ang II. Thus, we explored whether the response to natriuretic factors was altered by fructose by measuring the effect of the dopamine receptor 1 (D1) agonist fenoldopam on NHE3 activity. We found that, in tubules from FRUC rats, fenoldopam $\left(10^{-6} \mathrm{~mol} / \mathrm{L}\right)$ reduced the rate of $\mathrm{pH}$ recovery by $1.1 \pm 0.6 \mathrm{AFU} / \mathrm{s}(n=7)$. This value was not significantly different from the recovery rate in controls after the D1 agonist of $0.6 \pm 0.4 \mathrm{AFU} / \mathrm{s}(n=5 ;$ Figure 6). This indicates that the enhanced sensitivity to Ang II is not mediated by an altered response to a natriuretic factor.

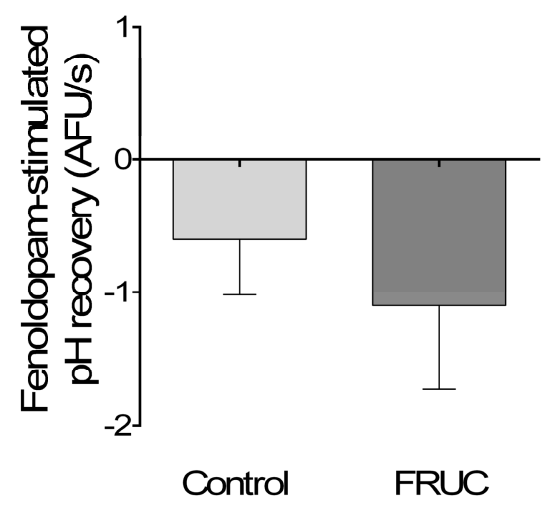

Figure 6. Effect of $10^{-6} \mathrm{~mol} / \mathrm{L}$ of the dopamine 1 receptor agonist fenoldopam on $\mathrm{pH}$ recovery after an $\mathrm{NH}_{4}$ pulse in proximal tubules from rats consuming either $20 \%$ fructose (FRUC) or tap water (Control).

\section{Discussion}

We previously reported that $20 \%$ fructose in the drinking water predisposes animals to salt-sensitive hypertension, and that acute exposure to fructose increases the sensitivity of control proximal tubules to Ang II [16]. In the present study, we explored whether dietary fructose enhances the ability of low concentrations of Ang II $\left(10^{-12} \mathrm{~mol} / \mathrm{L}\right)$ to augment proximal tubule Na reabsorption and the transporters involved. We also characterized the model showing that a moderately enriched fructose diet does not cause overt metabolic syndrome within seven days. Thus, it is important to distinguish the model presented here from models with longer-term treatments ( $\geq 2$ weeks) used to induce metabolic syndrome [52].

To test our hypothesis, we first measured whether a low concentration of Ang II $\left(10^{-12} \mathrm{~mol} / \mathrm{L}\right)$ stimulated $\mathrm{QO}_{2}$ by proximal tubule suspensions from rats given either $20 \%$ fructose or tap water. We found that a low Ang II $\left(10^{-12} \mathrm{~mol} / \mathrm{L}\right)$ increased $\mathrm{QO}_{2}$ by proximal tubules from rats given $20 \%$ fructose in their drinking water for a week but not in control suspensions.

$\mathrm{QO}_{2}$ can be used as a rapid screening tool for changes in transcellular Na transport because proximal tubules produce ATP via aerobic metabolism, and Na/K-ATPase uses $60-70 \%$ of the ATP supply to drive Na across the basolateral membrane. Thus, our data indicate that a $20 \%$ fructose diet causes low concentrations of Ang II to stimulate Na reabsorption.

One mechanism by which the response of Na reabsorption to a low concentration of Ang II could be enhanced is by increased expression of $\mathrm{Na}$ transporters. Consequently, we measured the expression of $\mathrm{Na}$ /K-ATPase and NHE3, which mediate $\mathrm{Na}$ exit from the cell across the basolateral membrane and most $\mathrm{Na}$ entry across the apical membrane, respectively. Our data indicate that a $20 \%$ fructose diet alters NHE3 but not Na/K-ATPase expression after one week. However, it is important to note that total transporter expression does not necessarily correlate with activity. Even more accurate measurements of transporter expression, such as the number of units in the plasma membrane, should be taken with caution when estimating transport rates. Thus, the modest increase in NHE3 reported here may or may not alter actual Na reabsorption in vivo.

To circumvent these problems and directly address transport, we measured Na/K-ATPase and NHE activities. We found that dietary fructose did not alter basal ouabain-sensitive ATP hydrolysis, 
a measure of $\mathrm{Na} / \mathrm{K}$-ATPase activity. Furthermore, a low concentration of Ang II did not affect $\mathrm{Na} / \mathrm{K}-\mathrm{ATP}$ ase activity in either FRUC or control suspensions. These data indicate that dietary fructose does not directly alter $\mathrm{Na} / \mathrm{K}$-ATPase activity or the ability of Ang II to regulate it. These experiments also show a trend of lower $\mathrm{Na} / \mathrm{K}$-ATPase activities in the FRUC group. Even though this difference was not significant, a shift in $\mathrm{Na} / \mathrm{K}-\mathrm{ATPa} e$ activity may represent the initiation of a pressure natriuretic response [53]. This counter regulatory mechanism could be buffering the enhanced sensitivity to Ang II to prevent elevations in blood pressure. Finally, a limitation of our results is that we did not study whether dietary fructose alters the $\mathrm{K}_{1 / 2}$ for either $\mathrm{Na}$ or $\mathrm{K}$. Given that intracellular $\mathrm{Na}$ is near the $\mathrm{K}_{1 / 2}$ of the $\mathrm{Na} / \mathrm{K}$-ATPase for $\mathrm{Na}$, a change in this parameter could alter activity. However, while Ang II has been reported to increase maximum $\mathrm{Na} / \mathrm{K}$-ATPase activity [54], there are no reports to our knowledge that it alters the $\mathrm{K}_{1 / 2}$ for $\mathrm{Na}$. It is unlikely that an increase in the affinity for $\mathrm{K}$ could affect $\mathrm{Na} / \mathrm{K}$-ATPase activity under normal physiological circumstances because $\mathrm{K}$ is nearly always saturating.

While assessing NHE3 activity, we found that a low concentration of Ang II increased pH recovery in proximal tubules from FRUC rats but not in controls. These results are the first to show such an effect, and likely explain the $\mathrm{QO}_{2}$ data. Examining these data, one might well ask how tubules from FRUC increase $\mathrm{QO}_{2}$ and NHE3 activity in response to Ang II $\left(10^{-12} \mathrm{~mol} / \mathrm{L}\right)$ without elevating $\mathrm{Na} / \mathrm{K}$-ATPase activity. The answer to this apparent discrepancy is rather simple. The $\mathrm{Na} / \mathrm{K}$-ATPase experiments were designed to test direct actions of Ang II on this transporter. Thus, ATP hydrolytic activity was measured in permeabilized tubules in which intracellular $\mathrm{Na}\left(\mathrm{Na}_{\mathrm{i}}\right)$ was equilibrated with the extracellular media. The corollary of the data is that the increase in $\mathrm{Na} / \mathrm{K}$-ATPase activity necessary to support higher transport rates in FRUC is not achieved by a direct effect of Ang II on this transporter; instead, an elevated intracellular Na secondary to an increase in NHE activity drives the $\mathrm{Na} / \mathrm{K}$-ATPase. This explanation is supported by the literature in which stimulation of proximal tubules with Ang II triggers transient increases in $\mathrm{Na}_{\mathrm{i}}$ of up to $8 \mathrm{mmol} / \mathrm{L}$ [32,55]. Such an increase in $\mathrm{Na}_{\mathrm{i}}$ would be expected to double the resting levels of about $10 \mathrm{mmol} / \mathrm{L}$ [32], and elevate $\mathrm{Na} / \mathrm{K}-\mathrm{ATPase}$ activity near to its maximum velocity [49].

Our data showing that dietary fructose enhances the sensitivity of proximal tubules to Ang II is novel, and the present study is the first addressing the chronic effect of fructose consumption on proximal tubule transport. However, the acute effects of fructose on tubular transport have been measured previously. We reported that short-term incubation with millimolar concentrations of fructose increase NHE activity in response to $10^{-12} \mathrm{~mol} / \mathrm{L}$ Ang II in isolated perfused proximal tubules [16]. Another group reported that millimolar concentrations of fructose increased bicarbonate transport in proximal tubules using micropuncture [56]. In both reports, the effects of fructose were unique and not shared by other hexoses [16,56].

Urinary and plasma fructose concentrations correlate with fructose intake [57-59] leading to elevated concentrations in the environment surrounding proximal tubules. The proximal tubule reabsorbs $\sim 70 \%$ of filtered water which would be expected to increase the intraluminal concentration of fructose by a factor of 3-4 compared to plasma. After ingesting a $20 \%$ fructose solution, the urinary concentration of fructose can reach up to $40 \mathrm{mmol} / \mathrm{L}$ in humans [60]. Based on this, the fructose concentration in the proximal tubule can be back calculated to $3-4 \mathrm{mmol} / \mathrm{L}$, comparable to concentrations that increase transport in vitro $[16,56]$. This suggests that the effects of a $20 \%$ fructose diet are likely due to fructose per se in the proximal tubule.

In our current work, we observed differences in transport rates in tubular suspensions and isolated perfused tubules, preparations in which variables such as arterial pressure, renal hemodynamics, plasma signaling molecules and even fructose itself have been eliminated. This necessarily means that the effects of fructose are not limited to short postprandial periods when fructose concentrations in plasma and urine are elevated. Thus, the effects of fructose are long-lasting and do not depend on acute changes in circulating factors or intact renal nerves and architecture. 
The mechanisms by which dietary fructose enables low concentrations of Ang II to stimulate proximal tubule Na reabsorption are not completely understood. We found that the PKC $\alpha / \beta_{1}$ inhibitor Gö6976 blunted the ability of a low concentration of Ang II to stimulate NHE activity in proximal tubules from rats fed $20 \%$ fructose. Thus, PKC $\alpha$ or $\beta_{1}$ likely are crucial to the actions of dietary fructose. Classical PKC isoforms $(\alpha, \beta, \gamma)$, which are diacylglycerol- and Ca-dependent, have been shown to mediate the stimulation of fluid and bicarbonate reabsorption caused by Ang II [23-26]. Activation of this family of kinases has been reported to increase in several tissues from fructose-fed rats [61,62]. Proximal tubules generate diacylglycerols from fructose via dihydroacetone-phosphate [63-66]. Thus, dietary fructose may be increasing diacylglycerol formation, which in turn primes PKC such that lower concentrations of Ang II can activate it and stimulate transport.

In contrast to the effect on NHE activity, dietary fructose does not allow a low concentration of Ang II to stimulate $\mathrm{Na}$ /K-ATPase activity. These results appear to be consistent with the literature, as PKC has been reported to have disparate effects on this transporter [67]. Early metabolic studies in proximal tubule suspensions showed that phorbol esters first stimulate and then inhibit ouabain-sensitive $\mathrm{QO}_{2}$. The stimulatory phase was inhibited by amiloride, and when $\mathrm{Na}_{\mathrm{i}}$ was equalized with amphotericin $B$ the inhibition phase was still observed. The authors concluded that the initial stimulation of $\mathrm{Na} / \mathrm{K}$-ATPase was secondary to an increase in $\mathrm{Na}_{\mathrm{i}}$ and the inhibitory effect was dependent on PKC [68]. Other studies demonstrated that the regulation of Na/K-ATPase by PKC is also modulated by PKA and $\mathrm{Na}_{\mathrm{i}}[67,69,70]$; and phorbol esters, which stimulate classical PKCs, inhibit $\mathrm{Na} / \mathrm{K}-\mathrm{ATPase}$ activity [70].

Finally, we tested whether alterations in natriuretic signaling contribute to the enhanced sensitivity to Ang II. We measured whether a $20 \%$ fructose diet affects dopamine signaling mediated by D1s because dopamine is a major regulator of proximal tubule transport [71,72] and D1s directly interact with the AT1R counteracting their actions $[73,74]$. Thus, a reduction in D1 signaling would result in less inhibition of the stimulatory effect of Ang II. Our results indicate D1 signaling is not impaired in this model; this is of particular importance since the interaction between D1 and AT1R occurs at the receptor level [75], which reinforces the idea that the changes in sensitivity to Ang II are due to downstream signaling.

In summary, consumption of $20 \%$ fructose in drinking water for one week causes an increase in transport rates by the proximal tubule in response to low concentrations of Ang II that is associated with intracellular pathways involving lipid-dependent PKC isoforms.

\section{Conclusions}

In industrialized countries, the average fructose consumption represents nearly $10 \%$ of the total caloric intake [1-3]. This sets the second quartile at risk of ingesting $20 \%$ or more of total calories as fructose [1-3]. The increase in the incidence of hypertension over the last 40 years mirrors the increase in dietary fructose and salt. Our present study suggests that part of the increase in blood pressure associated with fructose consumption is due to an enhanced Ang II sensitivity in proximal tubules. This may provide an explanation for why Ang II receptor blockers frequently reduce blood pressure to a greater extent than Ang II converting enzyme inhibitors. It also suggests that reducing dietary fructose in hypertensive patients may be comparable to reducing salt intake, with the added benefits of being easier for patients to reduce fructose intake over salt, given that better substitutes are available.

Acknowledgments: This work was supported in part by a grant from the Heart, Lung and Blood Institute of the National Institutes of Health to J.L.G. (HL128053).

Author Contributions: P.D.C., A.G.-V., F.P.D. and J.L.G. conceived and designed the experiments; P.D.C., A.G.-V., N.J.H., J.A., N.Y. and J.M.B. performed the experiments; P.D.C., A.G.-V. and J.L.G. analyzed the data; J.L.G. contributed reagents/materials/analysis tools; and P.D.C. and A.G.-V. wrote the paper. P.D.C. and A.G.-V. contributed equally to this manuscript.

Conflicts of Interest: The authors declare no conflict of interest. 


\section{References}

1. Sluik, D.; Engelen, A.I.; Feskens, E.J. Fructose consumption in the netherlands: The dutch national food consumption survey 2007-2010. Eur. J. Clin. Nutr. 2015, 69, 475-481. [CrossRef] [PubMed]

2. Montonen, J.; Jarvinen, R.; Knekt, P.; Heliovaara, M.; Reunanen, A. Consumption of sweetened beverages and intakes of fructose and glucose predict type 2 diabetes occurrence. J. Nutr. 2007, 137, 1447-1454. [PubMed]

3. Vos, M.B.; Kimmons, J.E.; Gillespie, C.; Welsh, J.; Blanck, H.M. Dietary fructose consumption among us children and adults: The third national health and nutrition examination survey. Medscape J. Med. 2008, 10, 160. [PubMed]

4. Libuda, L.; Alexy, U.; Buyken, A.E.; Sichert-Hellert, W.; Stehle, P.; Kersting, M. Consumption of sugar-sweetened beverages and its association with nutrient intakes and diet quality in german children and adolescents. Br. J. Nutr. 2009, 101, 1549-1557. [CrossRef] [PubMed]

5. Ogden, C.L.; Kit, B.K.; Carroll, M.D.; Park, S. Consumption of Sugar Drinks in the United States, 2005-2008; NCHS Data Brief; National Center for Health Statistics: Hyattsville, MD, USA, 2011; pp. 1-8.

6. Johnson, R.K.; Appel, L.J.; Brands, M.; Howard, B.V.; Lefevre, M.; Lustig, R.H.; Sacks, F.; Steffen, L.M.; Wylie-Rosett, J.; American Heart Association Nutrition Committee of the Council on Nutrition; Physical Activity; Metabolism and the Council on Epidemiology and Prevention. Dietary sugars intake and cardiovascular health: A scientific statement from the american heart association. Circulation 2009, 120, 1011-1020. [PubMed]

7. Jalal, D.I.; Smits, G.; Johnson, R.J.; Chonchol, M. Increased fructose associates with elevated blood pressure. J. Am. Soc. Nephrol. 2010, 21, 1543-1549. [CrossRef] [PubMed]

8. Johnson, R.J.; Sanchez-Lozada, L.G.; Nakagawa, T. The effect of fructose on renal biology and disease. J. Am. Soc. Nephrol. 2010, 21, 2036-2039. [CrossRef] [PubMed]

9. Schulze, M.B.; Manson, J.E.; Ludwig, D.S.; Colditz, G.A.; Stampfer, M.J.; Willett, W.C.; Hu, F.B. Sugar-sweetened beverages, weight gain, and incidence of type 2 diabetes in young and middle-aged women. JAMA J. Am. Med. Assoc. 2004, 292, 927-934. [CrossRef] [PubMed]

10. Ludwig, D.S.; Peterson, K.E.; Gortmaker, S.L. Relation between consumption of sugar-sweetened drinks and childhood obesity: A prospective, observational analysis. Lancet 2001, 357, 505-508. [CrossRef]

11. Nguyen, S.; Choi, H.K.; Lustig, R.H.; Hsu, C.Y. Sugar-sweetened beverages, serum uric acid, and blood pressure in adolescents. J. Pediatr. 2009, 154, 807-813. [CrossRef] [PubMed]

12. Hwang, I.S.; Ho, H.; Hoffman, B.B.; Reaven, G.M. Fructose-induced insulin resistance and hypertension in rats. Hypertension 1987, 10, 512-516. [CrossRef] [PubMed]

13. Nishimoto, Y.; Tomida, T.; Matsui, H.; Ito, T.; Okumura, K. Decrease in renal medullary endothelial nitric oxide synthase of fructose-fed, salt-sensitive hypertensive rats. Hypertension 2002, 40, 190-194. [CrossRef] [PubMed]

14. Sanchez-Lozada, L.G.; Tapia, E.; Jimenez, A.; Bautista, P.; Cristobal, M.; Nepomuceno, T.; Soto, V.; Avila-Casado, C.; Nakagawa, T.; Johnson, R.J.; et al. Fructose-induced metabolic syndrome is associated with glomerular hypertension and renal microvascular damage in rats. Am. J. Physiol. Ren. Physiol. 2007, 292, F423-F429. [CrossRef] [PubMed]

15. Vasdev, S.; Gill, V.; Parai, S.; Gadag, V. Fructose-induced hypertension in wistar-kyoto rats: Interaction with moderately high dietary salt. Can. J. Physiol. Pharmacol. 2007, 85, 413-421. [CrossRef] [PubMed]

16. Cabral, P.D.; Hong, N.J.; Hye Khan, M.A.; Ortiz, P.A.; Beierwaltes, W.H.; Imig, J.D.; Garvin, J.L. Fructose stimulates NA/H exchange activity and sensitizes the proximal tubule to angiotensin II. Hypertension 2014, 63, e68-e73. [CrossRef] [PubMed]

17. Gordish, K.L.; Kassem, K.M.; Ortiz, P.A.; Beierwaltes, W.H. Moderate (20\%) fructose-enriched diet stimulates salt-sensitive hypertension with increased salt retention and decreased renal nitric oxide. Physiol. Rep. 2017, 5, e13162. [CrossRef] [PubMed]

18. Beierwaltes, W.; Ismail, A.; Szandzik, D.; Garvin, J.; Ortiz, P. A fructose enriched diet (20\%) induces salt-sensitive hypertension and prevents salt-induced decrease in plasma renin. FASEB J. 2015, 29, S960.

19. Thomas, D.; Harris, P.J.; Morgan, T.O. Age-related changes in angiotensin II-stimulated proximal tubule fluid reabsorption in the spontaneously hypertensive rat. J. Hypertens. Suppl. 1988, 6, S449-S451. [CrossRef] [PubMed] 
20. Aldred, K.L.; Harris, P.J.; Eitle, E. Increased proximal tubule NHE-3 and H+-atpase activities in spontaneously hypertensive rats. J. Hypertens. 2000, 18, 623-628. [CrossRef] [PubMed]

21. Hall, J.E. Control of sodium excretion by angiotensin II: Intrarenal mechanisms and blood pressure regulation. Am. J. Physiol. 1986, 250, R960-R972. [PubMed]

22. Gurley, S.B.; Riquier-Brison, A.D.; Schnermann, J.; Sparks, M.A.; Allen, A.M.; Haase, V.H.; Snouwaert, J.N.; Le, T.H.; McDonough, A.A.; Koller, B.H.; et al. At1a angiotensin receptors in the renal proximal tubule regulate blood pressure. Cell Metab. 2011, 13, 469-475. [CrossRef] [PubMed]

23. Bertorello, A.M. Diacylglycerol activation of protein kinase $\mathrm{C}$ results in a dual effect on $\mathrm{Na}+, \mathrm{K}(+)$-ATPase activity from intact renal proximal tubule cells. J. Cell Sci. 1992, 101 Pt 2, 343-347. [PubMed]

24. Bertorello, A.M.; Katz, A.I. Short-term regulation of renal Na-K-ATPase activity: Physiological relevance and cellular mechanisms. Am. J. Physiol. 1993, 265, F743-F755. [PubMed]

25. Liu, F.Y.; Cogan, M.G. Role of protein kinase $\mathrm{C}$ in proximal bicarbonate absorption and angiotensin signaling. Am. J. Physiol. 1990, 258, F927-F933. [PubMed]

26. Du, Z.; Ferguson, W.; Wang, T. Role of PKC and calcium in modulation of effects of angiotensin II on sodium transport in proximal tubule. Am. J. Physiol. Ren. Physiol. 2003, 284, F688-F692. [CrossRef] [PubMed]

27. Iyer, S.N.; Katovich, M.J. Effect of chronic losartan potassium treatment on fructose-induced hypertension. Life Sci. 1994, 55, PL139-PL144. [CrossRef]

28. Kamari, Y.; Harari, A.; Shaish, A.; Peleg, E.; Sharabi, Y.; Harats, D.; Grossman, E. Effect of telmisartan, angiotensin II receptor antagonist, on metabolic profile in fructose-induced hypertensive, hyperinsulinemic, hyperlipidemic rats. Hypertens. Res. 2008, 31, 135-140. [CrossRef] [PubMed]

29. Iyer, S.N.; Katovich, M.J. Effect of acute and chronic losartan treatment on glucose tolerance and insulin sensitivity in fructose-fed rats. Am. J. Hypertens. 1996, 9, 662-668. [CrossRef]

30. Navarro-Cid, J.; Maeso, R.; Perez-Vizcaino, F.; Cachofeiro, V.; Ruilope, L.M.; Tamargo, J.; Lahera, V. Effects of losartan on blood pressure, metabolic alterations, and vascular reactivity in the fructose-induced hypertensive rat. Hypertension 1995, 26, 1074-1078. [CrossRef] [PubMed]

31. Harris, P.J. Regulation of proximal tubule function by angiotensin. Clin. Exp. Pharmacol. Physiol. 1992, 19, 213-222. [CrossRef] [PubMed]

32. Reilly, A.M.; Harris, P.J.; Williams, D.A. Biphasic effect of angiotensin II on intracellular sodium concentration in rat proximal tubules. Am. J. Physiol. 1995, 269, F374-F380. [PubMed]

33. Harris, P.J.; Navar, L.G.; Ploth, D.W. Evidence for angiotensin-stimulated proximal tubular fluid reabsorption in normotensive and hypertensive rats: Effect of acute administration of captopril. Clin. Sci. 1984, 66, 541-544. [CrossRef] [PubMed]

34. Barraclough, M.A.; Perriello, V.A.; Marsden, C.D.; Jones, N.F. The influence of the experimental conditions on the renal response to angiotensin in the rat. Experientia 1967, 23, 140-142. [CrossRef] [PubMed]

35. Barraclough, M.A.; Jones, N.F.; Marsden, C.D. Effect of angiotensin on renal function in the rat. Am. J. Physiol. 1967, 212, 1153-1157. [PubMed]

36. Kuroki, M.T.; Fink, G.D.; Osborn, J.W. Comparison of arterial pressure and plasma ANG II responses to three methods of subcutaneous ANG II administration. Am. J. Physiol. Heart Circ. Physiol. 2014, 307, H670-H679. [CrossRef] [PubMed]

37. Aoki, H.; Nakata, M.; Dezaki, K.; Lu, M.; Gantulga, D.; Yamamoto, K.; Shimada, K.; Kario, K.; Yada, T. Ghrelin counteracts salt-induced hypertension via promoting diuresis and renal nitric oxide production in dahl rats. Endocr. J. 2013, 60, 571-581. [CrossRef] [PubMed]

38. Seikaly, M.G.; Arant, B.S., Jr.; Seney, F.D., Jr. Endogenous angiotensin concentrations in specific intrarenal fluid compartments of the rat. J. Clin. Investig. 1990, 86, 1352-1357. [CrossRef] [PubMed]

39. Braam, B.; Mitchell, K.D.; Fox, J.; Navar, L.G. Proximal tubular secretion of angiotensin II in rats. Am. J. Physiol. 1993, 264, F891-F898. [PubMed]

40. Navar, L.G.; Harrison-Bernard, L.M.; Wang, C.T.; Cervenka, L.; Mitchell, K.D. Concentrations and actions of intraluminal angiotensin II. J. Am. Soc. Nephrol. 1999, 10 (Suppl. 11), S189-S195. [PubMed]

41. Nishiyama, A.; Seth, D.M.; Navar, L.G. Renal interstitial fluid concentrations of angiotensins I and II in anesthetized rats. Hypertension 2002, 39, 129-134. [CrossRef] [PubMed]

42. Krieger, J.E.; Liard, J.F.; Cowley, A.W., Jr. Hemodynamics, fluid volume, and hormonal responses to chronic high-salt intake in dogs. Am. J. Physiol. 1990, 259, H1629-H1636. [PubMed] 
43. Tank, J.E.; Moe, O.W.; Henrich, W.L. Abnormal regulation of proximal tubule renin mRNA in the Dahl/Rapp salt-sensitive rat. Kidney Int. 1998, 54, 1608-1616. [CrossRef] [PubMed]

44. Ying, J.; Stuart, D.; Hillas, E.; Gociman, B.R.; Ramkumar, N.; Lalouel, J.M.; Kohan, D.E. Overexpression of mouse angiotensinogen in renal proximal tubule causes salt-sensitive hypertension in mice. Am. J. Hypertens. 2012, 25, 684-689. [CrossRef] [PubMed]

45. Reed, M.J.; Ho, H.; Donnelly, R.; Reaven, G.M. Salt-sensitive and carbohydrate-sensitive rodent hypertension: Evidence of strain differences. Blood Press. 1994, 3, 197-201. [CrossRef] [PubMed]

46. Catena, C.; Cavarape, A.; Novello, M.; Giacchetti, G.; Sechi, L.A. Insulin receptors and renal sodium handling in hypertensive fructose-fed rats. Kidney Int. 2003, 64, 2163-2171. [CrossRef] [PubMed]

47. Huang, D.Y.; Boini, K.M.; Friedrich, B.; Metzger, M.; Just, L.; Osswald, H.; Wulff, P.; Kuhl, D.; Vallon, V.; Lang, F. Blunted hypertensive effect of combined fructose and high-salt diet in gene-targeted mice lacking functional serum- and glucocorticoid-inducible kinase SGK1. Am. J. Physiol. Regul. Integr. Comp. Physiol. 2006, 290, R935-R944. [CrossRef] [PubMed]

48. Boesch, D.M.; Garvin, J.L. Age-dependent activation of PKC isoforms by angiotensin II in the proximal nephron. Am. J. Physiol. Regul. Integr. Comp. Physiol. 2001, 281, R861-R867. [PubMed]

49. Gonzalez-Vicente, A.; Garvin, J.L. Angiotensin II-induced hypertension increases plasma membrane Na pump activity by enhancing Na entry in rat thick ascending limbs. Am. J. Physiol. Ren. Physiol. 2013, 305, F1306-F1314. [CrossRef] [PubMed]

50. Gonzalez-Vicente, A.; Cabral, P.D.; Garvin, J.L. Resveratrol increases nitric oxide production in the rat thick ascending limb via $\mathrm{Ca}^{2+} /$ calmodulin. PLoS ONE 2014, 9, e110487. [CrossRef] [PubMed]

51. Garvin, J.L. Angiotensin stimulates bicarbonate transport and $\mathrm{Na}^{+} / \mathrm{K}^{+}$ATPase in rat proximal straight tubules. J. Am. Soc. Nephrol. 1991, 1, 1146-1152. [PubMed]

52. Toop, C.R.; Gentili, S. Fructose beverage consumption induces a metabolic syndrome phenotype in the rat: A systematic review and meta-analysis. Nutrients 2016, 8, 577. [CrossRef] [PubMed]

53. Magyar, C.E.; Zhang, Y.; Holstein-Rathlou, N.H.; McDonough, A.A. Downstream shift in sodium pump activity along the nephron during acute hypertension. J. Am. Soc. Nephrol. 2001, 12, 2231-2240. [PubMed]

54. Yingst, D.R.; Massey, K.J.; Rossi, N.F.; Mohanty, M.J.; Mattingly, R.R. Angiotensin II directly stimulates activity and alters the phosphorylation of Na-K-ATPase in rat proximal tubule with a rapid time course. Am. J. Physiol. Ren. Physiol. 2004, 287, F713-F721. [CrossRef] [PubMed]

55. Wong, P.S.; Johns, E.J. The receptor subtype mediating the action of angiotensin II on intracellular sodium in rat proximal tubules. Br. J. Pharmacol. 1998, 124, 41-46. [CrossRef] [PubMed]

56. Queiroz-Leite, G.D.; Crajoinas, R.O.; Neri, E.A.; Bezerra, C.N.; Girardi, A.C.; Reboucas, N.A.; Malnic, G. Fructose acutely stimulates NHE3 activity in kidney proximal tubule. Kidney Blood Press. Res. 2012, 36, 320-334. [CrossRef] [PubMed]

57. Song, X.; Navarro, S.L.; Diep, P.; Thomas, W.K.; Razmpoosh, E.C.; Schwarz, Y.; Wang, C.Y.; Kratz, M.; Neuhouser, M.L.; Lampe, J.W. Comparison and validation of 2 analytical methods for measurement of urinary sucrose and fructose excretion. Nutr. Res. 2013, 33, 696-703. [CrossRef] [PubMed]

58. Luceri, C.; Caderni, G.; Lodovici, M.; Spagnesi, M.T.; Monserrat, C.; Lancioni, L.; Dolara, P. Urinary excretion of sucrose and fructose as a predictor of sucrose intake in dietary intervention studies. Cancer Epidemiol. Prev. Biomark. 1996, 5, 167-171.

59. Hallfrisch, J.; Ellwood, K.; Michaelis, O.E.T.; Reiser, S.; Prather, E.S. Plasma fructose, uric acid, and inorganic phosphorus responses of hyperinsulinemic men fed fructose. J. Am. Coll. Nutr. 1986, 5, 61-68. [CrossRef] [PubMed]

60. Rohrer, G.V.; Welsh, J.D. Urinary fructose excretion after fructose loadin. Before and after portal-systemic shunting. Arch. Surg. 1968, 96, 979-982. [CrossRef] [PubMed]

61. Donnelly, R.; Reed, M.J.; Azhar, S.; Reaven, G.M. Expression of the major isoenzyme of protein kinase-C in skeletal muscle, $\mathrm{nPKC}$ theta, varies with muscle type and in response to fructose-induced insulin resistance. Endocrinology 1994, 135, 2369-2374. [CrossRef] [PubMed]

62. Donnelly, R.; Chang, H.; Azhar, S.; Reaven, G.M. Tissue-dependent activation of protein kinase C in fructose-induced insulin resistance. Endocrine 1995, 3, 129-133. [CrossRef] [PubMed]

63. Burch, H.B.; Cole, B.; Choi, S.; Alvey, T.R.; Dence, C. Diversity of effects of fructose loads on different parts of the nephron. Int. J. Biochem. 1980, 12, 37-40. [CrossRef] 
64. Burch, H.B.; Narins, R.G.; Chu, C.; Fagioli, S.; Choi, S.; McCarthy, W.; Lowry, O.H. Distribution along the rat nephron of three enzymes of gluconeogenesis in acidosis and starvation. Am. J. Physiol. 1978, 235, F246-F253. [PubMed]

65. Diggle, C.P.; Shires, M.; Leitch, D.; Brooke, D.; Carr, I.M.; Markham, A.F.; Hayward, B.E.; Asipu, A.; Bonthron, D.T. Ketohexokinase: Expression and localization of the principal fructose-metabolizing enzyme. J. Histochem. Cytochem. 2009, 57, 763-774. [CrossRef] [PubMed]

66. Cirillo, P.; Gersch, M.S.; Mu, W.; Scherer, P.M.; Kim, K.M.; Gesualdo, L.; Henderson, G.N.; Johnson, R.J.; Sautin, Y.Y. Ketohexokinase-dependent metabolism of fructose induces proinflammatory mediators in proximal tubular cells. J. Am. Soc. Nephrol. 2009, 20, 545-553. [CrossRef] [PubMed]

67. Efendiev, R.; Pedemonte, C.H. Contrary to rat-type, human-type Na,K-ATPase is phosphorylated at the same amino acid by hormones that produce opposite effects on enzyme activity. J. Am. Soc. Nephrol. 2006, 17, 31-38. [CrossRef] [PubMed]

68. Yingst, D.R.; Araghi, A.; Doci, T.M.; Mattingly, R.; Beierwaltes, W.H. Decreased renal perfusion rapidly increases plasma membrane Na-K-ATPase in rat cortex by an angiotensin II-dependent mechanism. Am. J. Physiol. Ren. Physiol. 2009, 297, F1324-F1329. [CrossRef] [PubMed]

69. Cheng, X.J.; Hoog, J.O.; Nairn, A.C.; Greengard, P.; Aperia, A. Regulation of rat Na(+)-K(+)-ATPase activity by PKC is modulated by state of phosphorylation of Ser-943 by PKA. Am. J. Physiol. 1997, 273, C1981-C1986. [PubMed]

70. Efendiev, R.; Bertorello, A.M.; Zandomeni, R.; Cinelli, A.R.; Pedemonte, C.H. Agonist-dependent regulation of renal $\mathrm{Na}+, \mathrm{K}+-$ ATPase activity is modulated by intracellular sodium concentration. J. Biol. Chem. 2002, 277, 11489-11496. [CrossRef] [PubMed]

71. Sanada, H.; Jose, P.A.; Hazen-Martin, D.; Yu, P.Y.; Xu, J.; Bruns, D.E.; Phipps, J.; Carey, R.M.; Felder, R.A. Dopamine-1 receptor coupling defect in renal proximal tubule cells in hypertension. Hypertension 1999, 33 , 1036-1042. [CrossRef] [PubMed]

72. Jose, P.A.; Eisner, G.M.; Felder, R.A. Role of dopamine receptors in the kidney in the regulation of blood pressure. Curr. Opin. Nephrol. Hypertens. 2002, 11, 87-92. [CrossRef] [PubMed]

73. Zeng, C.; Wang, Z.; Hopfer, U.; Asico, L.D.; Eisner, G.M.; Felder, R.A.; Jose, P.A. Rat strain effects of AT1 receptor activation on D1 dopamine receptors in immortalized renal proximal tubule cells. Hypertension 2005, 46, 799-805. [CrossRef] [PubMed]

74. Zeng, C.; Jose, P.A. Dopamine receptors: Important antihypertensive counterbalance against hypertensive factors. Hypertension 2011, 57, 11-17. [CrossRef] [PubMed]

75. Khan, F.; Spicarova, Z.; Zelenin, S.; Holtback, U.; Scott, L.; Aperia, A. Negative reciprocity between angiotensin II type 1 and dopamine D1 receptors in rat renal proximal tubule cells. Am. J. Physiol. Ren. Physiol. 2008, 295, F1110-F1116. [CrossRef] [PubMed]

(C) 2017 by the authors. Licensee MDPI, Basel, Switzerland. This article is an open access article distributed under the terms and conditions of the Creative Commons Attribution (CC BY) license (http://creativecommons.org/licenses/by/4.0/). 